\title{
Potential and Determinants of Carbon Storage of Freshwater Swamp Forests in the Niger Delta
}

\author{
Nwabueze I. Igu ${ }^{1,2 *}$, Rob Marchant ${ }^{1}$ \\ ${ }^{1}$ York Institute for Tropical Ecosystems (KITE), Environment Department, University of York, York, UK \\ ${ }^{2}$ Department of Geography and Meteorology, Nnamdi Azikiwe University, Awka, Nigeria \\ Email: *nwabuezeigu@gmail.com
}

How to cite this paper: Igu, N.I. and Marchant, R. (2017) Potential and Determinants of Carbon Storage of Freshwater Swamp Forests in the Niger Delta. Open Journal of Ecology, 7, 199-210. https://doi.org/10.4236/oje.2017.73015

Received: February 7, 2017

Accepted: March 24, 2017

Published: March 27, 2017

Copyright (c) 2017 by authors and Scientific Research Publishing Inc. This work is licensed under the Creative Commons Attribution International License (CC BY 4.0).

http://creativecommons.org/licenses/by/4.0/ (c) (i) Open Access

\begin{abstract}
There has been an increase in carbon assessments across global ecosystems, but some ecosystem types remain woefully understudied-freshwater swamp forests are one such ecosystem. Results of the above ground carbon estimates are derived from 16, one-hectare forest plots divided evenly across four forest sites. Results on carbon storage are compared with results on forest use and ownership from interviews with communities living in the area. Since forest use determined the composition, structure and the capacity of the ecosystem to sequester carbon; its above ground carbon decreased from the undisturbed forest plots to the disturbed (modified) sites across the sites. Forest units under communal ownership demonstrated possibilities of actualizing targeted/ restricted use of tree species, as well as targeted carbon storage capacities. Even though joint ownership and management schemes are likely to regulate the use of the ecosystem, and possibly enhance better carbon sequestration, achieving this still seems elusive due to a long existing land tenure system and generational inheritance of (forest) lands across the region. Carbon sequestration across the region will remain under threat unless suitable awareness on forest management is backed up with alternative sources of livelihood, incentives and compensation to the custodians of the forest resources.
\end{abstract}

\section{Keywords}

Climate Regulation, Forest Carbon, Forest Management, Mangrove Transition, Modified Ecosystems, Nigeria, REDD+

\section{Introduction}

Freshwater swamp forests support high levels of biodiversity for which the Niger Delta is renowned [1]. Located between the mangrove swamp forest and the 
lowland forest ecosystems, freshwater swamp forest provides a corridor for the migration of flora and fauna between these ecosystems as well as being floristically unique [2]. Swamp forests contribute to the provision of ecosystem services across the Nigerian state and like other tropical forests, are potential stores of carbon and important for climate regulation and biogeochemical cycling [3] [4]. Swamp forests support the majority of households across the region that has depended on it for subsistence and livelihood, over the last 400 years [5]. However, this ecosystem has been steadily exploited, its extent has reduced, been degraded and is now confined to small pockets across the Niger Delta. As a result, its species like in most other old growth forests across the tropics [6] [7], are not only threatened and fragmented, but the ecosystem services they provide are reduced. These changes have impacted the forest landscape adversely and reduced the former extensive ecosystem into mosaics of forest islands.

Disturbance and degradation associated with the use of the forests are responsible for modifying the composition, their biodiversity and conservation prospects [8] [9]. Hence, with variations in frequency and patterns of use of the freshwater swamp forests across the Niger Delta, some of the native species (such as Hallea ledermannii (K. Krause) Verdc.) have almost become extinct in many locations across the ecosystem; while some other economically important trees (such as Milicia excelsa C. C. Berg) have become very rare across the region. With most of the "species (economic trees)" in the ecosystem continually facing harvesting pressure, maintaining stable climax species composition across most of the forest landscapes in the region has remained difficult [10] [11]. As these trees are either selectively logged or cleared, they are on the other hand replaced by other (heliophilous) species such as the palms.

Palms (such as Elaeis guineensis) naturally occur in a variety of habitats such as river valleys in forest zones, open/dry forests, gallery forests, secondary forests and freshwater swamp forests [12] [13] [14] [15], especially where insolation and moisture are available at ground level [15]. Such suitable environments are created through disturbances (mainly from anthropogenic influences) accruing from forest use (such as for agricultural and logging purposes) across the freshwater ecosystem. As disturbances continue in the ecosystem, the forest canopies and vegetation structure become more open and the microclimatic conditions become more altered and promote the establishment and growth of palms. On the other hand, since the proceeds from the palms (such as palm oil and wine) have remained the main source of livelihood for the people of the region for centuries [16], the people not only became attached to the tree and encouraged its growth, but rarely $\log$ it in the forests.

Since the use of the ecosystem are dependent on the management and ownership statuses of the forest lands, understanding the linkages between the management of the ecosystem and the services they provide is crucial to maximize ecosystem service potentials. We focus on highlighting the impact of forest use on the composition and the carbon storage capacities of the ecosystem; so as to better inform and promote the ecosystem's conservation and its carbon poten- 
tials.

\section{Materials and Methods}

\subsection{Study Area}

The Niger Delta is the largest river delta in Africa [17]. With numerous creeks dotted across the region, this unique delta supports rich floral and faunal diversity that is of regional and international importance [18] [19]. The region is a vast sedimentary basin located between Latitude $4^{\circ}$ and $6^{\circ}$ north of the Equator and Longitudes $5^{\circ}$ and $7^{\circ}$, east of the Greenwich. It is found in the lower reaches of the River Niger and River Benue (Figure 1); that was formed from the accumulated sediments derived from the Niger and Benue basins, the Volta River basin, and minor rivers within Nigeria [20]. Soils of the region are classified as hydromorphic soils that are either seasonally or permanently waterlogged [21]. The region is characterized by a long rainy season that lasts nearly throughout the year (mainly between March and October) and a short dry season (mainly between December and February). Its annual precipitation increases from the north of the Delta (an average of $2500 \mathrm{~mm} \cdot \mathrm{yr}^{-1}$ ) to the coastal areas where its mean annual rainfall averages around $4000 \mathrm{~mm} \cdot \mathrm{yr}^{-1}$ [22].

Situated at the apex of the Gulf of Guinea and in the southern part of Nigeria (Figure 1), the region covers all the oil producing states of Nigeria, from which the bulk of Nigeria's oil and gas reserves, wealth and foreign exchange are sourced [23]. The region has a rich cultural heritage and is ethnically varied; with ethnic groups such as Ijo, Efik, Ibibio, Bini, Isoko/Ukwani, Urhobo and Itsekiri found across the region. Settlements across the region are predominantly rural and composed of people that are culturally attached to the environment. Most of the people living in the region are quite poor and the unemployment and underemployment rates ( $8.8 \%$ and $26.2 \%$ respectively) across the region are higher than that of other regions in the country [24]. Underemployment in this context is defined as a situation in which workers are under-utilized or employed below their skill, education, capacity and experience.

\subsection{Data Collection}

A standard plot based method was used to conduct a vegetation survey by establishing sixteen 1 ha plots across the ecosystem in four locations: Akarai-Obodo, Akili-Ogidi, Otuwe and Akoloma (Figure 1) between December 2013 and April 2014. Each of the plots was further divided into blocks of $20 \times 20 \mathrm{~m}$ (25 subplots) to manage the tree enumeration. All tree species that were $\geq 10 \mathrm{~cm}$ diameter at breast height (DBH) were measured and identified. Trees were identified in the field following the taxonomy of Nigerian plants [25]. While most of these species were enumerated and identified to species level in the field, voucher specimens were collected for unidentified species that were verified at the herbarium in Forest Research Institute of Nigeria, Ibadan. Smaller tree stems were omitted as they contain approximately $5 \%$ of above ground carbon [26] 
[27]. Tree heights were determined using a laser rangefinder, and where the tree height was less than $10 \mathrm{~m}$, graduated poles was used to measure the height. The forest sites were selected to capture variation in species composition, carbon storage potentials, as well as use and management dynamics. While AkaraiObodo, Akili-Ogidi and Otuwe are freshwater swamp forests, Akoloma is a mangrove-freshwater transition forest (Figure 1). Akili-Ogidi, Akarai-Obodo and Akoloma are secondary forests that are managed by people from the nearby communities; whereas Otuwe is an undisturbed forest that is very remote and inaccessible either during the rainy or dry season.

Information on forest use, management and ownership (Appendix) was collected from the forest communities using interviews and informal discussions. This was targeted at the community leaders, aged individuals (mainly male community members aged 65 years and above) and key informants (such as youth leaders and school teachers) where possible. Aged individuals (and other key informants) were targeted for the survey because they had good knowledge
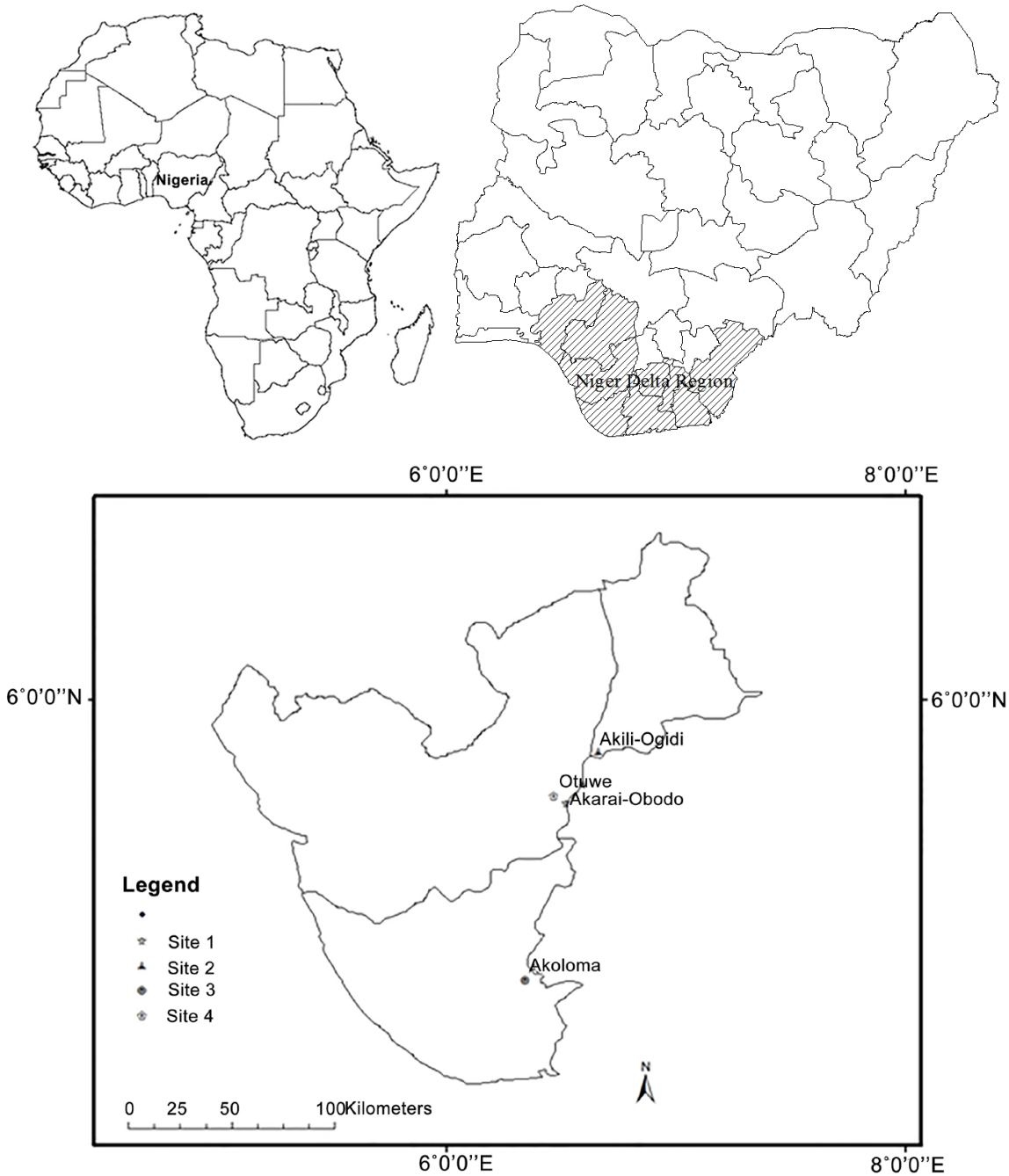

Figure 1. Map of the study locations in the Niger Delta with the Nigerian and African map inset. 
(and were custodians) of the traditions, customs and practices in the different communities. They are equally aware of both land-forest matters and other day-to-day norms. Each of the respondents was interviewed individually so that they could comfortably express their views. This method of collecting information enabled in-depth views to be collected from respondents and also gave the opportunity for follow-up questions where necessary.

\subsection{Data Analysis}

Taxon-specific average values of wood specific gravity (WSG) for each of the stems across the forest plots were extracted from the database on global wood density [28]; and used to calculate the above ground carbon. Depending on data available, mean values for genus, family or current plot were used (respectively) in situations where the WSG of any of the species were not available. Palm species' biomass and carbon were estimated with the mean of palm species (WSG = $0.55 \mathrm{~g} \cdot \mathrm{cm}^{-3}$ ) for the entire tropics, since the African mean value was absent. Each tree biomass was eventually calculated with Chave et al. [29] pantropical equation as follows:

$$
A G B=0.0673 \times\left(\rho D^{2} H\right)^{0.976}
$$

where AGB is the above ground biomass; $\rho$ is the wood specific gravity (WSG; $\left.\mathrm{g} \cdot \mathrm{cm}^{-3}\right) ; \mathrm{D}$ is the diameter at breast height $(\mathrm{DBH} ; \mathrm{cm})$ and $\mathrm{H}$ is the height $(\mathrm{m})$. The biomass for each tree was estimated to contain $50 \%$ above ground carbon throughout the study [30].

To show how the above ground carbon (AGC) estimates varied across the forest locations and across the plots within each of the forest locations, a one way ANOVA was conducted; since it satisfied the parametric test assumptions. A Kruskal Wallis test was used to show how the AGC varied with intensities of use of the forest sites. This non-parametric test was used in this case, as it did not satisfy the parametric test assumptions. Intensities of use (with the presence/occurrence data of palm as a proxy) were ranked (from 1 to 4); from least to mostly used. Shapiro Wilk test were used to test for normality of the data. The analyses were performed with $\mathrm{R}$ statistical software version 3.1.0 (cran.r-project.org).

\section{Results}

\subsection{Above Ground Carbon Estimates and Influences}

The above ground carbon varied across the forest locations/sites $(\mathrm{F}=8.55, \mathrm{DF}=$ $3, \mathrm{p}=0.0026$ ); with Otuwe location which is the least modified or degraded forest location, recording the highest value of AGC than the other forest locations.

The extent of modification encountered across the disturbed landscapes (Akarai-Obodo, Akili-Ogidi and Akoloma) (Table 1) are proxies to understanding the degrees to which the AGC potentials have been reduced (following the replacement of native species with palms across the landscape). Even though that the sites in Akoloma had enormous presence of palms (were much modified), the 
Table 1. Summary of the forest ownership status, use and restrictions in forest use, as well as the mean values of carbon and occurrence of palms across the sites.

\begin{tabular}{cccl}
\hline Location & $\begin{array}{c}\text { Mean of } \\
\text { carbon (t/ha) }\end{array}$ & $\begin{array}{c}\text { Mean of palm } \\
\text { (per/ha) }\end{array}$ & \multicolumn{1}{c}{ Ownership, use \& Restriction } \\
\hline Akarai-Obodo & $74.75 \pm 26.31$ & $32.25 \pm 9.46$ & $\begin{array}{l}\text { Family owned; no restriction in use; used } \\
\text { frequently for timber \& non-timber forest } \\
\text { products (NTFP) }\end{array}$ \\
Akili-Ogidi & $134.3 \pm 17.42$ & $50.25 \pm 25.71$ & $\begin{array}{l}\text { Communally owned; restricted from using Milicia } \\
\text { excelsa; used frequently for timber \& NTFPs }\end{array}$ \\
Akoloma & $116.33 \pm 45.15$ & $109.25 \pm 29.33$ & $\begin{array}{l}\text { Family owned; no restriction in use; used } \\
\text { frequently for timber \& NTFPs }\end{array}$ \\
Otuwe & $199.1 \pm 44.4$ & $0.25 \pm 0.5$ & $\begin{array}{l}\text { Family owned; used seasonally for fishing } \\
\text { activities only }\end{array}$ \\
\hline
\end{tabular}

higher number of more carbon dense trees (Rhizophoraceae) contributed to its high AGC when compared to the other disturbed landscapes in Akili-Ogidi.

\subsection{Forest Ownership, Use and Relationship with AGC}

While the forest plots at Akarai-Obodo and Akoloma are under family management, the forest plots at Akili-Ogidi are managed communally. Otuwe forest site though owned by different families from Akarai-Obodo, is very far away from the community and only used (that is the lake in its environs) for seasonal fishing activities. Akarai-Obodo and Akoloma forest locations had no forms of restrictions to forest use, as the forests were exploited by its owners (Table 1). Akili-Ogidi forest site is owned and managed communally; it served the community members who needed it for different purposes (such as hunting, firewood collection and non-timber forest products). Even though it was logged as in other secondary forest sites, there were restrictions as regards its use (Table 1). Across the forest communities: Akarai-Obodo, Akili-Ogidi and Akoloma, the forests were used as the main sources of timber and non-timber forest products such as forest fruits, vegetables and nuts. It equally served as sources of fuelfirewood, medicine (herbs) and used for hunting game. The swamps in the forests served as fishing grounds, while the forest lands were mainly used for agricultural activities.

The AGC of the forest locations differed across the sites mainly due to the variations in intensities of use (Kruskal-Wallis $\chi^{2}=10.65, \mathrm{DF}=3, \mathrm{p}=0.013$ ). Hence, Otuwe site which had the least intensity of use (least modification in terms of palm presence) and frequency of use (seasonally), recorded a higher mean AGC compared to the remaining locations (put together), that were used on more frequent occasions. Restrictions of use associated with the ownership type demonstrate the possibilities of achieving species conservation (e.g. Milicia excelsa; Table 1) across communally owned forest landscapes.

\section{Discussion}

Freshwater swamp forests are important stores of carbon and contribute to cli- 
mate change mitigation across the Niger Delta region [31]; however, the capacity to which it could act as store for carbon is dependent on the state of the forest, the current extent and how disturbed or intact the forests is. The results of this study showed a higher AGC storage in intact forest locations (which had a higher biomass), than the disturbed forest landscapes (with smaller biomass). Similar results have been reported across other African forest landscapes [3]. Apart from the issue of large/small biomass, the modifications across the ecosystem following anthropogenic interferences (such as logging and agricultural activities), equally affected the total AGC of the (modified/disturbed sites) ecosystem. This was more evident across the modified forest landscapes in the region: AkaraiObodo, Akili-Ogidi and Akoloma, where human impacts on the ecosystem are responsible for the abundance and growth of monocots like the palms in the ecosystem. Though palms grow naturally in both pioneer and secondary swamp forests [32], they become more abundant in modified (disturbed) forest ecosystems (as in freshwater swamp) where open canopies and modified (drier and hotter) microclimatic conditions promotes their abundance [33]. Their presence was highest in the Akoloma site than in the other disturbed landscapes because the forest canopies in this location were more open (more disturbed) and its environment drier, than in the other locations, possibly due to a higher elevation than in other locations.

Such modifications in the ecosystem alters the composition of the ecosystem, threatens forest-dependent species in the landscape, and will also act as microclimatic barriers to the growth of other native species that are adapted to the moist freshwater swamp terrain [33] [34]. Since the livelihood of the people across the region promotes the growth of palms, it has continually contributed to the modification of the ecosystem's composition especially across the disturbed forest sites. While there is no doubt that such forest-agricultural landscapes have the capacity to store carbon in the above ground biomass of its taxa (like the Palms), they cannot be compared with the capacities found in dominant and pioneer species (such as Sterculia oblonga Mast. and Rhizophora racemosa G. Mey) in the ecosystem. Ensuring that taxa within the forest ecosystem are not being replaced by other less carbon dense taxa in instances where the forests become degraded, are vital steps to ensuring a higher potential carbon sequestration for the ecosystem.

Forest use has both shaped and contributed to the biodiversity modifications of freshwater swamps and its composition at landscape levels across the region. This is mostly due to the pattern of forest harvesting as well as the purpose for such activities. Since the forests are made up of trees of diverse age and composition, mass tree felling is rarely practiced; instead, selective loggings of trees that are in demand by commercial timber operators are the norm. This has the potential of not only reducing the forest cover and composition of the ecosystem, but equally contribute to the damage of the forest's area and making its species, especially the ones with small ranges become scarce [35]. As the intensity of forest use increases across the landscape, and most of the forest lands are converted 
into agricultural or forest-agricultural landscapes by its owners (either for personal farming or rented out to migrant farmers), the capacity to which they store AGC is reduced. This pressure from agricultural activities at subsistence and commercial levels are not only the main underlying causes of forest loss in a majority of the forest communities in the region [36], but a threat to long term AGC store and biodiversity conservation. As most of the rural landscapes across the freshwater zone are mostly engaged in agro-based economies, land use changes and conversions are likely to continue its debilitating effects on ecosystem services unless alternative sources of livelihood and forest friendly initiatives are upheld across the agricultural landscapes in the region.

Forest ecosystems in most forest communities in the Niger Delta region are mainly under private (family) and community ownership holdings. These ownership structures/levels are responsible for the use and preservation of the forest landscapes and equally influence the composition, service provision and viability of the ecosystem. Community ownership and management of the forest lands offers viable management and use of forests by its ability to enforce restrictions to forest use as well as more centralized forest governance for the benefit of the entire community members. Hence, in a location like Akili-Ogidi (whose forest plots are within community forest lands), restrictions on the logging of Milicia excelsa for commercial purposes helped to ensure that this high-market value tree (which are very rare in forest ecosystems in the region), are preserved in its forests. This tree species was more frequent at Akili-Ogidi, as against a single occurrence in Akoloma and no occurrences in Akarai-Obodo due to a general lack of regulation in logging across these sites.

While communal management structures may be potentially useful in preserving the native species in the freshwater swamp forests in the region and the carbon storage potentials of the ecosystem, they are not viable in communities predominated by individual/family ownership structures. The forest character in areas under private (individual/family) holdings are influenced by the needs and socio-economic status of the families, as well as influences from commercial timber operators, who put the families under intense pressure to permit them $\log$ the high value timber trees in their forest lands. Such family ownership, span from single family ownership to the next of kin, depending on how united the families are and the size of forest lands to be inherited. Most family units are characterized by individuals with different socio-economic levels and interests. As a result, forest lands are being divided in a bid to either ensure that each one gets his inheritance or to settle conflicting interests on forest use over the years. Managing such extensive forest units that are owned by different individuals with varied needs have not only become highly complicated, but has continually made conservation prioritization of such landscapes very difficult. In a bid to properly manage such forest ecosystems and sites (under private ownership), a more unified system of ownership, management and decision-making have been advocated across most African nations [37] [38]. While this seems to be a likely strategy to promote good forest management and guided use of the ecosystem 
services across the region, the feasibility of achieving it in a region with deeply entrenched land tenure system and a trend/norm of family land (forest) inheritance may not be feasible. With the bulk of forest lands and majority of the undisturbed forests under private ownership and management across the region, the future of ecosystem service provision across the region depends to a large extent on how the people use the ecosystem.

\section{Conclusion}

Forest ownership and utilization can affect forest composition and its capacity to provide vital ecosystem services such as carbon storage. The capacity to which freshwater swamp forests across the region stored carbon seems to be on the decline following forest modification across most of the landscapes. This has become more acute because, the forests' management and viability are dependent on individuals who mostly depend on the forests for sources of livelihood and barely consider issues of forest conservation. Awareness of sustainable forest management techniques need to be advocated across both family owned and communally owned forests-in order to ensure that their carbon storage capacities are not hampered. In addition to the provision of alternative sources of livelihood, supporting such awareness is likely to reduce the rate of forest degradation. With this, the ecosystem would be able to continually provide carbon sequestration across the ecosystem and contribute to global carbon budgets.

\section{Acknowledgements}

This research is part of the $\mathrm{PhD}$ work of the first author which was supported by the Nigerian government. We are grateful to the taxonomists from the Forest Research Institute that helped with species identification, leaders of the host communities as well as the individuals that participated in the research and forest surveys.

\section{References}

[1] UNDP (2006) Niger Delta Human Development Report. United Nations Development Program, Lagos.

[2] James, G.K. (2008) Assessment of Environmental Change and Its Socio-Economic Impacts in the Mangrove Ecological Zone of the Niger Delta, Nigeria. PhD Thesis, University of Missouri, Kansas City, Missouri.

[3] Lewis, S.L., Sonke, B., Sunderland, T., Begne, S.K., Lopez-Gonzalez, G., van der Heijden, G.M.F., Phillips, O.L., Affum-Baffoe, K., Baker, T.R., Banin, L., et al. (2013) Aboveground Biomass and Structure of 260 African Tropical Forests. Philosophical Transactions of the Royal Society B, 368. https://doi.org/10.1098/rstb.2012.0295

[4] Cavaleri, M.A., Reed, S.C., Smith, W.K. and Wood, T.E. (2015) Urgent Need for Warming Experiments in Tropical Forests. Global Change Biology, 21, 2111-2121. https://doi.org/10.1111/gcb.12860

[5] World Wildlife Fund (2014) Niger Delta Swamp Forests. http://www.eoearth.org/view/article/154853 
[6] Laurance, W.F., Camargo, J.L.C., Luizão, R.C.C., Laurance, S.G., Pimm, S.L., Bruna, E.M., Stouffer, P.C., Williamson, G.B., Benítez-Malvido, J., Vasconcelos, H.L., Houtan, K.S.V., Zartman, C.E., Boyle, S.A., Didham, R.K., Andrade, A. and Lovejoy, T.E. (2011)The Fate of Amazonian Forest Fragments: A 32-Year Investigation. Biological Conservation, 144, 56-67.

[7] Kessler, M., Hertel, D., Jungkunst, H.F., Kluge, J., Abrahamczyk, S., Bos, M., Buchori, D., Gerold, G., Gradstein, S.R., Köhler, S., Leuschner, C., Moser, G., Pitopang, R., Saleh, S., Schulze, C.H., Sporn, S.G., Steffan-Dewenter, I., Tjitrosoedirdjo, S.S. and Tscharntke, T. (2012) Can Joint Carbon and Biodiversity Management in Tropical Agroforestry Landscape be Optimized? PLoS ONE, 7, e47192.

https://doi.org/10.1371/journal.pone.0047192

[8] Chazdon, R.L., Peres, C.A., Dent, D., Sheil, D., Lugo, A.E., Lamb, D., Stork, N.E. and Miller, S.E. (2009) The Potential for Species Conservation in Tropical Secondary Forests. Conservation Biology, 23, 1406-1417. https://doi.org/10.1111/j.1523-1739.2009.01338.x

[9] Van Breugel, M., Hall, J.S., Craven, D., Bailon, M., Hernandez, A., Abbene, M. and Van Breugel, P. (2013) Succession of Ephemeral Secondary Forests and Their Limited Role for the Conservation of Floristic Diversity in a Human-Modified Tropical Landscape. PLoS ONE, 8, e82433. https://doi.org/10.1371/journal.pone.0082433

[10] Joseph, L.N., Maloney, R.F. and Possingham, H.P. (2009) Optimal Allocation of Resources among Threatened Species: A Project Prioritization Protocol. Conservation Biology, 23, 328-338. https://doi.org/10.1111/j.1523-1739.2008.01124.x

[11] Bisong, F.E. and Buckley, P. (2014) Threat Status of Commercially Exploited Trees in the Nigerian Rainforest. Open Journal of Forestry, 4, 536-546. https://doi.org/10.4236/ojf.2014.45058

[12] Hartley, C.W.S. (1977) The Oil Palm. Tropical Agriculture Series. 2nd Edition, Longman, London.

[13] Sowunmi, M.A. (1981) Nigerian Vegetational History from the Late Quaternary to the Present Day. Palaeoecology of Africa, 13, 217-234.

[14] Swaine, M.D. and Hall, J.B. (1986) Forest Structure and Dynamics. In: Lawson, G.W., Ed., Plant Ecology in West Africa: Systems and Processes, Wiley, New York.

[15] Sowunmi, M.A. (1999) The Significance of the Oil Palm (Elaeis guineensis Jacq.) in the Late Holocene Environments of West and West Central Africa: A Further Consideration. Vegetation History and Archaeobotany, 8, 199-210. https://doi.org/10.1007/BF02342720

[16] Aghalino, S.O. (2000) British Colonial Policies and the Oil Palm Industry in the Niger Delta Region of Nigeria, 1900-1960. African Study Monographs, 21, 19-33.

[17] Dupont, L.M., Jahns, S., Marret, F. and Ning, S. (2000) Vegetation Change in Equatorial West Africa: Time-Slices for the Last $150 \mathrm{ka}$. Palaeogeography, Palaeoclimatology, Palaeoecology, 155, 95-122.

[18] Happold, D.C. (1987) The Mammals of Nigeria. Clarendon Press, Oxford, UK.

[19] Hilton-Taylor, C. (2000) IUCN Red List of Threatened Species. IUCN, Gland, Switzerland and Cambridge, UK.

[20] Allen, J.R.L. (1964) Coastal Geomorphology of Eastern Nigeria: Beach Ridge Barrier Islands and Vegetated Tidal Flats. Geologie en Mijnbouw, 44, 1-21.

[21] Areola, O. (1982) Soils. In: Barbour, K.M., Oguntoyinbo, J.S., Onyemelukwe, J.O.C. and Nwafor, J.C., Eds., Nigeria in Maps, Hodder and Stoughton, London, 22-23.

[22] Niger Delta Master Plan (2005) Niger Delta Region, Land and People. Niger Delta Regional Development Master Plan, Federal Republic of Nigeria.

[23] Ite, A.E., Ibok, U.J., Ite, M.U. and Petters, S.W. (2013) Petroleum Exploration and 
Production: Past and Present Environmental Issues in the Nigeria's Niger Delta. American Journal of Environmental Protection, 1, 78-90. https://doi.org/10.12691/env-1-4-2

[24] Ukiwo, U. (2009) Causes and Cures of Oil-Related Niger Delta Conflicts. Policy Notes 1. The Nordic Africa Institute.

[25] Keay, R.W.J. (1989) Trees of Nigeria. Clarendon Press, Oxford, UK.

[26] Lewis, S.L., Lopez-Gonzalez, G., Sonke, B., Affum-Baffoe, K., Baker, T.R., Ojo, L.O., Phillips, O.L., Reitsma, J.M., White, L., Comiskey, J.A., et al. (2009) Increasing Carbon Storage in Intact African Tropical Forests. Nature, 457, 1003-1006. https://doi.org/10.1038/nature07771

[27] Marshall, A.R., Willcock, S., Platts, P.J., Lovett, J.C., Balmford, A., Burgess, N.D., Latham, J.E., Munishi, P.K.T., Slater, R., Shirima, D.D. and Lewis, S.L. (2012) Measuring and Modeling Above-Ground Carbon and Tree Allometry along a Tropical Gradient. Biological Conservation, 154, 20-33.

[28] Zanne, A.E., Lopez-Gonzalez, G., Coomes, D.A., Ilic, J., Jansen, S., Lewis, S.L., Miller, R.B., Swenson, N.G., Wiemann, M.C. and Chave, J. (2009) Global Wood Density Database. Dryad Identifier. http://hdl.handle.net/10255/dryad.235

[29] Chave, J., Réjou-Méchain, M., Burquez, A., Chidumayo, E., Colgan, M.S., Delitti, W.B.C., Duque, A., Eid, T., Fearnside, P.M., Goodman, R.C., Henry, M., MartínezYrízar, A., Mugasha, W.A., Muller-Landau, H.C., Mencuccini, M., Nelson, B.W., Ngomanda, A., Nogueira, E.M., Ortiz-Malavassi, E., Pélissier, R., Ploton, P., Ryan, C.M., Saldarriaga, J.G. and Vieilledent, G. (2015) Improved Allometric Models to Estimate the Aboveground Biomass of Tropical Trees. Global Change Biology, 20, 3177-3190. https://doi.org/10.1111/gcb.12629

[30] Chave, J., Andalo, C., Brown, S., Cairns, M.A., Chambers, J.Q., Eamus, D., Folster, H., Fromard, F., Higuchi, N., Kira, T., Lescure, J.P., Nelson, B.W., Ogawa, H., Puig, H., Riera, B. and Yamakura, T. (2005) Tree Allometry and Improved Estimation of Carbon Stocks and Balance in Tropical Forests. Oecologia, 145, 87-99. https://doi.org/10.1007/s00442-005-0100-x

[31] Igu, N.I. (2016) Freshwater Swamp Forest Ecosystem in the Niger Delta: Ecology, Disturbance and Ecosystem Services. PhD Thesis, University of York, Heslington, UK.

[32] Runge, J. (2008) Dynamics of Forest Ecosystems in Central Africa during the Holocene, Past-Present-Future. CRC Press, Boca Raton.

[33] Luskin, M.S. and Potts, M.D. (2011) Microclimate and Habitat Heterogeneity through the Oil Palm Lifecycle. Basic and Applied Ecology, 12, 540-551.

[34] Fitzherbert, E.B., Struebig, M.J., Morel, A., Danielsen, F., Brühl, C.A., Donald, P.F. and Phalan, B. (2008) How Will Oil Palm Expansion Affect Biodiversity? Trends in Ecology and Evolution, 23, 538-545.

[35] Pimm, S.L. and Raven, P. (2000) Biodiversity: Extinction by Numbers. Nature, 403, 843-845. https://doi.org/10.1038/35002708

[36] Enaruvbe, G.O. and Atafo, O.P. (2014) Analysis of Deforestation Pattern in the Niger Delta Region of Nigeria. Journal of Land Use Science, 11, 113-130. https://doi.org/10.1080/1747423X.2014.965279

[37] Lund, J.F. and Treue, T. (2008) Are We Getting There? Evidence of Decentralized Forest Management from the Tanzanian Miombo Woodlands. World Development, 36, 2780-2800.

[38] Robinson, E.J.Z., Albers, H.J., Meshack, C. and Lokina, R.B. (2013) Implementing REDD through Community-Based Forest Management: Lessons from Tanzania. Natural Resources Forum, 37, 141-152. https://doi.org/10.1111/1477-8947.12018 


\section{Appendix}

Table A1. List of questions used to assess forest ownership, use and management.

\begin{tabular}{cl}
\hline S/N & \\
\hline 1 & Questions \\
2 & Who owns the forest(s) in your locality? \\
3 & What is the frequency of forest visit or use in your locality? \\
4 & Are there any restrictions to forest use in your environment? \\
5 & How are the forests managed/who takes care of the forests? \\
6 & Are there any laws guiding the use of the forests? \\
7 & $\begin{array}{l}\text { Are there any tree(s) that forest users are prevented by law from harvesting or log- } \\
\text { ging? }\end{array}$ \\
\hline
\end{tabular}

\section{Submit or recommend next manuscript to SCIRP and we will provide best} service for you:

Accepting pre-submission inquiries through Email, Facebook, LinkedIn, Twitter, etc. A wide selection of journals (inclusive of 9 subjects, more than 200 journals)

Providing 24-hour high-quality service

User-friendly online submission system

Fair and swift peer-review system

Efficient typesetting and proofreading procedure

Display of the result of downloads and visits, as well as the number of cited articles Maximum dissemination of your research work

Submit your manuscript at: http://papersubmission.scirp.org/

Or contact oje@scirp.org 